International Journal of Instruction e-ISSN: 1308-1470 • www.e-iji.net

Article submission code: 20201201195529

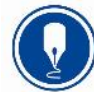

January $2022 \bullet$ Vol.15, No.1

p-ISSN: 1694-609X

pp. $73-88$

Received: 01/12/2020

Revision: 01/06/2021
Accepted: 30/06/2021

OnlineFirst: 10/10/2021

\title{
A Linguistic Ethnography of Discursive Identities of an English for Medical Purposes (EMP) Teacher
}

Omar Ali Al-Smadi

Institute of Public Administration, Jeddah \& University of Ha'il, Ha'il, Saudi Arabia, omarsmadi91@yahoo.com

\section{Radzuwan Ab Rashid}

Corresponding author, Faculty of Languages and Communication, Universiti Sultan Zainal Abidin, Terengganu, Malaysia, radzuwanrashid@unisza.edu.my

\section{Baderaddin Yassin}

Al-Ghad International Colleges for Applied Medical Sciences, Riyadh, Saudi Arabia, byassin@gc.edu.sa

\section{Hadeel Saad}

English Language and Translation Department, Applied Science Private University, Amman, Jordan, h_alsaed@asu.edu.jo

This study is a linguistic ethnographic investigation of teacher identities in an English for Medical Purposes (EMP) classroom at one of the medical colleges in the kingdom of Saudi Arabia. It focuses on the discursive shifts of teacher identities in his classroom interactions. An eclectic qualitative methodology that incorporated principles of Linguistic Ethnography was employed in this study. Classroom observation was the main method for data collection. When necessary, an informal conversation with the teacher was carried out after classroom observation to obtain further clarification of what had happened during the observation. The class was observed for 13 times during the first semester of the academic year 2019/2020. Five salient identities were constructed by the teacher: the expert, the counsellor, the student, the storyteller and the controller. These identities were found to be fluid and multiple and became temporarily salient in different classroom interactions. The teacher mediated classroom discourses by constantly shifting relationships and identities along the inclines of power. This study concludes that teacher's discursive identities portray positive self-image and account for students' active engagement and involvement in the learning process.

Keywords: classroom interaction, discursive identity, English for medical purposes, learning, linguistic ethnography, teacher

Citation: Al-Smadi, O. A., Rashid, R. A., Yassin, B., \& Saad, H. (2022). A linguistic ethnography of discursive identities of an English for medical purposes (EMP) teacher. International Journal of Instruction, 15(1), 73-88. https://doi.org/10.29333/iji.2022.1515a 


\section{INTRODUCTION}

Classroom interaction is an essential part of learning in which teachers and students collaborate to achieve learning (Al-Smadi \& Rashid, 2019; Othman et al., 2020; Rashid et al., 2017). The problematic construction of teachers' identities and relationships with students affect short and/or long-term learning of students and therefore provoke failure to engage in learning process (Al-Smadi et al., 2020). According to Koca (2017), the relationships which the teachers develop with students influence the students' academic progression, performance, and motivation to succeed. Teacher-student relationship is the key to allow other aspects of classroom to work well (Riyanto \& Aryulina, 2020; Abugohar et al., 2019). Trusting relationships between teachers and students lead to better regulation of classroom behavior and thus better learning environments (Tnay et al., 2020; Azizan et al., 2020). Therefore, this study sought to reveal the discursive identities constructed by the teacher in an EMP classroom to offer useful insights regarding the learning experiences engaged by the EMP learners.

The exploration of identity has been accounted for in several perspectives, such as educational perspective, sociolinguistic perspective, and the psychological perspective. However, according to Gee (2000), the clear-cut definition of identity has taken on "a great many different meanings in the literature" (p. 99). Lawler (2014) talks about the hopelessness of "offering a single, overarching definition of what it is, how it is developed, and how it works" (p. 7). Apart from these hitches, a fruitful start is a concept that "identity inhabits not mind, but the public and the accountable realm of discourse [where it] is performed, constructed, enacted, or produced, moment-tomoment, in everyday conversations" (Benwell \& Stokoe, 2006, p. 49).

The conceptualization of identity to that of Benwell and Stokoe's (2006) resonates with the definition of identity as "being recognized as a certain kind of person in a given context" (Gee, 2000, p. 99). Looking at identity from Benwell and Stokoe's (2006) and Gee's (2000) viewpoints endorses identity as something fluid, in which individuals have multiple identities based on the recognition of how other members of society perceive their behavior. Discursive identity or "D-identity" as Gee (2000) calls it accentuates the socio-constructionist characteristic of this identity type as something which anyone cannot "achieve all by oneself" (p. 103). Conversely, identity cannot be considered as a personal role or an attribute, it is an "emergent feature" of public contacts (Benwell \& Stokoe, 2006, p. 50).

Teacher identity has received significant attention in the process of language teaching and learning in the last few decades. Teacher identity is a complex and dynamic process in which characters experience continuous change and struggle due to external and internal factors (Salinas \& Ayala, 2018; Zare-ee \& Ghasedi, 2014; Bloomfield, 2010; Lamote \& Engels, 2010; Trent, 2013). Teachers construct and re-construct their identities as early as the start of teaching occupations and their identities develop through the years as they acquire new experiences. 


\section{Literature Review}

Discursive identity is a lively achievement of a person attribute (Benwell \& Stokoe, 2006; Gee, 2000). According to Benwell and Stokoe (2006), a person can "resist" in case they have no intention to be recognized by a certain identity (p. 70). According to Richards (2006), the achievement and ascription of identity over speech are possibly achieved as individuals consciously or unconsciously construct and expose things about themselves and the image they wish to convey about themselves whenever they speak. While Richards (2006) reveals that discursive identity construction might be unconscious, Gee (2014) affirms the consciousness of the construction mechanism "as writers or speakers, we actualize position design and recipient design" (p. 21). Recipient design is changing the fashion of writing or speaking determined by the type of addressees. For example, the way we address or talk to friends is different from the way we talk to strangers in an attempt to show "social distance" (Gee, 2014, p. 23). Position design on the other hand is changing the fashion of writing or speaking to show the addressee the intended image of self and thus tolerating our accomplishment of "desired identities" (Gee, 2014, p. 21).

The acknowledgement and achievement of discursive identity are expressive with the Goffman's "self-presentation" (Goffman, 1959, p. 4). Goffman claims that "when an individual appears in the presence of others, there will usually be some reason for him to mobilize his activity so that it will convey an impression to others which is in his interest to convey" (p. 4).

The achievement of discursive identity might be expressed using Edwards' (2005) discursive psychology strategies of extreme case formulation, assessment, and factual description. "The extreme case formulation" refers to the use of extreme words such as "the most" to show the speaker's attitude or stance (Edwards, 2005, p. 269). "Assessment" is linked to evaluative words to express disagreement, compliment, disagreement, requests etcetera (Edwards, 2005, p. 266). "The factual description" is the tactic in which the individual utilizes descriptive statements that appeared to be witnessed and true in several incidents and is predictable (Edwards, 2005, p. 262), and avoid imposing conclusions when constructing a certain character or personality. Edwards further noted that extreme case formulation, assessment, and factual description which he says could be done more operatively through the use of "emotion terms" as individuals usually react to emotions constructively (Edwards, 2005, p. 263).

Davies (1989) and Haniford (2010) agree that the central underlying belief of the discursive identity construction is that people have no stable identity as identities are formed and re-formed through several discursive performances in which they partake. Alternatively, Haniford (2010) claims that discursive identity performances are subject to a particular context, and the position disciplined by humans in certain social spaces. Appreciating discursive identities entails more than oral investigation of speech, it is also essential to embrace several socio-cultural features of speech like the place, time, and individuals involved to appreciate educators' discursive identities within certain contexts. Identities constructed in the discourse involving colleagues in a workplace are different from those constructed by teachers and students in the classroom. Classroom 
interactions afford instructors a platform to construct identities in which they are seen by multiple addressees.

In classroom interactions, teachers' discursive identities are formed through engagement in classroom activities with other students, therefore it is fluid instead of being fixed as multiple identities are constructed in several contexts. To be ascribed or accomplished, people might employ various types of discursive psychology strategies and impressionmanagement techniques to construct their desired identities (see Rashid et al., 2016a; 2016b).

There are numerous aspects of theories within discursive methods to educational research that are established over the last three decades. These theoretical aspects have been established in different directions; the understanding of discourses; how discourses operate and develop and how analysis in a discursive viewpoint can be carried out (Mohammadi \& Izadpanah, 2019; Nor \& Rashid, 2018). The notion of discourse can be used and understood in different ways and may contain different elements and phenomena (Al-Smadi et al., 2020).

Discourses produce and make discursive practices such as patterns of acting and thinking and narratives. These practices are produced by teachers and students in psychological and social realities. Discursive practices may be implicit, explicit, informal, or formal (Richards, 2006).

\section{METHOD}

This empirical study aims to investigate the discursive shifts of identities in EMP classroom interactions. Classroom observation was the main method for data collection. Thirteen classroom observations with the same group of students took place in the entire first semester of the academic year 2019/2020. The semester began in September 2019 and ended in January 2020. Each session lasted for one hour hence 13 hours of observation data were generated during the five months of data generation period.

When necessary, an informal chat with the teacher was carried out after classroom observation to get further clarification of what had happened during the observation. Examples of questions during informal chats are: Why do you frequently motivate students individually? Do you often plan your lessons? What makes you share personal narratives?

The class consisted of 20 male students, aged from 18 to 22 . The students sat for the Oxford Placement Test at the beginning of the semester. The results showed that the students were on the A2 level based on the Common European Framework of Reference for language learning. A2 level students are capable of handling simple straightforward information and have the ability to express themselves in familiar contexts (Aziz et al., 2018). The teacher involved in this study is a native Arab aged 37 with over 15 years of English language teaching experience. He has a master's degree in Teaching English as a Foreign Language, and he has attended several workshops in developing excellence in teaching. 
Using a qualitative approach which is broadly ethnographic and meticulously attended to unfolding discourse, this study employed elements from linguistic ethnography, discourse analysis, thematic analysis, and discursive psychology to analyze data and offer in-depth understanding on how the teacher constructs desirable identities. Using an eclectic qualitative approach not only enabled this study to analyze structural aspects of talk, but also allowed to account for functional and contextual aspects of talk. This includes pauses, laughter, gestures, body language, tone of voice, quotation, narratives, questioning behavior, feedback, initiation, sequencing, turn-asking, and criticizing.

The observations were videotaped and audiotaped for analysis. Classroom recorded data were all transcribed. The following codes were used in the transcription: (CO2, M7) refers to classroom observation number two, minute seven, and (IC) refers to informal chats. The names of the students are replaced by $(\mathrm{S} 1, \mathrm{~S} 2, \mathrm{~S} 3$ etcetera) and the name of the teacher is replaced by $(\mathrm{T})$.

\section{FINDINGS}

The teacher in this study constructed five salient identities: the expert, the counselor, the student, the storyteller, and the controller. The teacher constructs these identities in the classroom to project the image which enables him to gain acceptance and approval, thus creating a supportive learning environment. It is important to highlight here that these identities are fluid and that they become temporarily salient in different classroom interactions, which resonates with the views of Benwell and Stokoe (2006) who suggest that identities are discursively constructed "moment-to-moment" (p. 49). For example, a teacher who constructs the identity of a student in an episode may construct the identity of an expert in another episode of talk.

\section{The Expert}

The teacher was a good facilitator to his learners in the classroom. He showed concern for his students. He supported and directed them and developed a comfortable learning environment. Also, he encouraged his students to reach their aims by giving them more time to explore and share content and knowledge, for example, he helped the students to access resources and developed the autonomy of the students. The teacher facilitated learning processes by using different approaches such as pair work, group work, projectbased learning, and online learning. Moreover, the teacher offered advice and support to all students when needed which was seen in his movement in class during pair and group work to offer help and provide necessary scaffolding. The expert role of the teacher made it possible for optimal classroom learning. The following transcript illustrates the expert's identity of the teacher.

\section{Extract 4.1}

S6: What word for patient high sugar?

T: Diabetes

S10: How I say this word?

T: Glucometer

S12: What RR her?

6 T: It is abbreviation for Respiration rate 
7 S18: What name of this area? (The student was pointing to abdomen).

8 T: Abdomen

9 S1: What high fowler?

10 T: Sitting at 90 degrees (The teacher modelled the position for the students).

(CO10, M44).

The teacher in the previous extract was moving around the classroom to help the students with their group work. Each group of students was working on a different topic. The students asked several questions (lines 1,3,5, 7,9) to help them successfully complete the task. The teacher offered answers to the students' questions (lines 2, 4, 6, $8,10)$. In this extract, it is obvious that the teacher offered clear instructions because the students did not ask any questions regarding the direction or expectation of the task. The students asked questions regarding the appropriate word/s which they can use to finish the task. The teacher offered the appropriate language model and he also acted out one of the answers (line 10) for the sake of comprehension.

Extract 4.2 below further illustrates the expert identity of the teacher.

\section{Extract 4.2}

$\mathrm{T}$ : What does the glucometer measure?

S1: Blood pressure.

T: Ok S1. Can you tell me what the name of this device is?

S1: Sphygmomanometer.

T: Ok... What does sphygmomanometer measure?

S1: Blood pressure.

T: Brilliant... Now, does glucometer and sphygmomanometer have the same function?

S1: No... Glucometer for sugar blood.

10 T: Excellent S1... Bravo... Glucometer is used to measure the level of blood

11 sugar... Sphygmomanometer is used to measure blood pressure.

12 T: What is the name of patient with high blood sugar?

13 S2: Diabetic.

14 T: Brilliant S2... Diabetic.... and what is the name of patient with high blood

15 pressure?

16 S3: Hypertension.

17 T: Excellent S3... We call him or her hypertensive patient. Ok... hypertensive.

(CO3, M41).

The teacher brought two medical devices to classroom, namely a glucometer and a sphygmomanometer because he expected the students to get confused of their use. Therefore, he wanted to link the name and the function of those medical devices with an image which is quite familiar to all students. As shown in this transcript, the student was not able to offer correct answer to the teacher's question (line 2). The teacher did not offer immediate corrective feedback; rather, he asked the student another question (line 3 ) to guide him to the correct answer. The moment the student has seen the device (line 3 ), he knew that he made a mistake and therefore was able to answer other questions correctly (lines 4, 6, 9). Also, the teacher used this scenario to review the name of 
patients who suffer from diabetes and hypertension and even link the name of device with the function they serve and the type of patient they are used with (lines 12, 13, 14, $15,16)$.

The teacher constructs the identity of an expert mainly through offering clarification, guidance and feedback. The teacher employed discursive psychology strategies, such as offering clues and questions to direct the students toward intended meaning and comprehensible input.

\section{The Caring/Counselor}

Most people can remember their best teacher by name. When asked about what they remember most about this teacher, most responses will be toward the teacher's care for each student. Students will tell that they are recognized, respected, and understood for their distinctive interests and abilities by their teachers.

Teachers who bank on their students' capabilities show that they care through engaging the students at the heart of the learning processes. Students' engagement is necessary to make teaching fun, enduring, and expressive. The caring teachers constantly enhance and reflect on their instructional methods to make sure that the essentials of their students' needs are met.

The teacher did not make it a secret that he cares. He motivated the students by praising them, encouraging them, engaging them, and rewarding them. He frequently asked about things outside the class and remembered what the students shared about their personal lives such as asking about their diet and how they are doing in the soccer league that was discussed in one of the lessons. The following transcript illustrates the counsellor identity of the teacher.

\section{Extract 4.3}

1 T: Don't worry... All of you are my sons. I will take care of you and help

2 you pass the course.

(CO4, M50).

In this extract, the teacher directly reassures the students that he will help them achieve success and pass the course (lines $1 \& 2$ ) because exams are of major importance to the students. The teacher also showed that he does not only care about his course, but also about other subjects which are perceived difficult for students. The following transcript illustrates this.

\section{Extract 4.4}

1 T: How did you guys do in your physics test? I know it is hard but

2 you are up to it.

(CO7, M7).

In this transcript, the teacher showed that he cares about the students and he also expressed his understanding about the difficulty of the physics course by saying 'I know it is hard' (line 1). By saying this, the teacher showed interest in what bothers the students or what might be difficult for them. Acknowledgment and expressing 
understanding proved that the teacher cares about the students. Moreover, the teacher also motivated the students by saying 'you are up to it' (line 2).

The following transcript further illustrates the counsellor identity of the teacher. In this transcript, the teacher expressed his sympathy to one of the students who lost his father during the semester. The teacher believed that the students need support in such an issue and therefore he supported the students and motivated him.

\section{Extract 4.5}

1 T: I understand how difficult it is for you... sudden death is the worse...

2 but you can make him proud... I am sure your father has always wanted to

3 see you a better student and this is what you exactly need to do.

(CO3, M10).

The teacher in this transcript showed his sympathy for the loss of the student and he acknowledged that it is difficult to accept (line 1). However, the teacher did not want the student to surrender and become a victim of sorrow; the teacher motivated the student to achieve what he is supposed to achieve (lines 2,3). The teacher motivated the student to be strong and take the effort to please his late father by achieving what he expected him to do (line 3).

In the following transcript, the teacher asked the student to reflect on his teaching style. Asking students about learning preferences illustrates the counsellor identity of the teacher.

\section{Extract 4.6}

1 T: I want to ask you about the style of teaching... I mean am I rushing? Or

2 am I going slow? Do I make myself clear? ... Is there anything you do not

3 like in the class... Tell me your honest opinion about our class?

(CO5, M 50).

The teacher in this transcript showed that he cares about his students' learning styles and habits. The teacher asked for the students' reflections on his teaching. This teacher's concern about the students' needs and likes showed that he cares about the students and he is not only concerned about offering lessons, rather he respects and admires the students' preferences and he wants to make sure that everyone enjoys his classes and therefore establishes a family-like classroom atmosphere. Also, the teacher treated himself as a member of the class which is evident in the use of the pronoun 'our' in (line 5). In this sense, the teacher did not isolate himself from the sense of belonging in his class. The teacher asked directly for the students' opinions about their learning experiences to show that he cares for their interests and preferences.

The teacher constructs the identity of a counselor mainly through showing care to the students' needs and interests and by motivating the students to achieve personal goals.

\section{The student}

Students and teachers are both teachers and learners. Learners teach their instructors through the answers they offer in response to the instructor's questions, designs, ideas, and knowledge. The teacher models the role of a learner in the classroom as he worked 
with students in group work, for example, learn from his student's responses and use them in his talk, and share his personal stories about learning, take continuous feedback and reflection from his students and share barriers of learning with his students. The following transcript illustrates the student identity of the teacher.

\section{Extract 4.7}

1 T: S11... You are going to be our teacher on Thursday's lesson...

2 You have the right to ask questions and play the role of teacher... I am 3 going to be a student and you are going to answer our questions.

(CO8, M50).

The teacher in the previous extract displays the student identity. He considered himself a student and offered the power of the teacher to S11 (line 1) which is evident when he said you have the right to ask question (line 2). Also, the use of the pronoun "our" (lines $1 \& 3$ ) indicates that the teacher has approved himself as a student.

The following transcript further illustrates the student identity of the teacher.

\section{Extract 4.8}

1 S17: Teacher... many words to study... We don't know what to do

2 T: It's ok guys... keep up the spirit... I understand what do you

3 mean... I was a student before... I know things are sometimes confusing

4 and hard, but your hard work and practice will not go for nothing...

5 S7: You think we do good

6 T: Of course... Let me tell you this... When I was your age, I was not as

7 good as you ... but look at me now...

(CO5, M47).

The teacher motivated the students by assuring them that their hard work will help them when needed (line 4). The teacher also expressed that he understands how things are difficult for the student as he was a student before (line 3).

The teacher constructs the identity of a student mainly through minimizing his powerful role as a teacher and by positioning himself at the same level of his students.

\section{The storyteller}

The teacher constructs the identity of a storyteller when he tried to fit the genre of a story. Generally speaking, a genre is the "generic structure or a number of textual categories, such as sermons, stories, jokes, or lectures" (Thornbury and Slade, 2006, p. 146). Extract 4.9 illustrates one of the stories unfolded by the teacher.

\section{Extract 4.9}

1 T: When I was a kid, my father took me to hospital as I suffered from bad

2 cough and having fever... the idea of going to hospital was not fascinating

3 to me that time and it was frightening ... I mean... I was afraid to see a

4 doctor as the name doctor was usually used to threaten me to stop being

5 naughty and noisy... anyway once we reached there and saw the doctor...

guess what... he decided to give me an injection... problem now... I hate 


\begin{abstract}
injections... I started to cry, shout and begging my father to go home... I am ok now... I don't feel sick anymore... but the two of them gave me no chance... I mean taking the injection is a must in their opinion... my father started to give me offers like I will buy you ice cream and toys... that did not work with me because I buy ice cream everyday ... I mean nothing new ... taking an injection for an ice cream is not tempting at all ... so I kept yelling and shouting to go home... now the big man in white turn... I mean the doctor... can you imagine what did he say... it is not painful... is he serious I was thinking... I told him you lie to me... I know it is painful... I kept crying and begging my father to go home... guess what now... they had enough of me... no more sweet talk... I was shouted at and pushed to relax and lay down ... then you guys can imagine the rest....
\end{abstract}

(CO9, M22).

In this story, the telling of personal experience was to get students' attention, creating an interest in the subject matter, and therefore encouraging participation, understanding the subject through real-life experiences, and creating a sense of humor in the classroom. In narrating the story, the teacher positioned himself as a fragile individual and survivor. The use of possessive pronouns such as 'me' in the story by the teacher suggest the different hypothetical position he took. The teacher aligned with the students in two ways: he took the weaker position with those who share the same feelings and at the same time the rebel and survivor one with those who are strong. By doing so and through acting and the raising of the voice, the teacher created an ideal atmosphere for injecting the intended language while having the attention of all the students.

Referring to Wortham's (2001) model, the story was narrated from the view of a firsthand witness which made it authoritative and credible. Also, in the story, the teacher mentioned that he has been shouted at which can be explained as being a kid who was requested to do his best by his father and by the doctor (whom he regarded as monsters in his eye as they expect him to do the impossible) i.e. being relaxed while taking injection for instance. During the narration of the story, students adopted a kidlike identity which was seen in their behavior of making jokes, having fun, and appreciating their role as students.

\title{
The controller
}

Language classrooms incorporate several interactional activities that involve students' active participation. In the language classroom, students have opportunities to speak, argue, and read aloud. Such activities sometimes encourage disorder and noise, and thus, if the teacher inappropriately managed the class, the risk of disruptive behavior and chaos is highly expected. Noise and disruptive behavior in the classroom arbitrate the cognitive processing of information.

The identity of the controller is mainly salient when the teacher attempted to stop the students' disruptive behavior. In contrast with the previously constructed counsellor, 
expert, and student identities, the teacher constructed the identity of the controller using various discursive strategies.

The following transcript illustrates the controller identity of the teacher.

Extract 4.10

1 T: I already told you several times the use of mobile phones is not

2 allowed... How many times do I have to repeat myself ...? Do not make

3 me talk like this ... I hate to do this.

(CO4, M 12).

The teacher showed his disagreement with the use of the mobile phone (line 1). The teacher also in line 2 used the question of how many times do I have to repeat myself to express his wonder and dissatisfaction with the use of the mobile phone in the classroom. Also, the teacher expressed in line 3 that this is something he does not like to say to his students. Moreover, the teacher chose to address the whole class in this issue to make sure no one uses a mobile phone and avoid directly criticizing the one who used the mobile phone, which is evident in the teacher's use of the pronoun you (line 1).

Extract 4.11 below further illustrates the controller identity of the teacher. In this extract, the teacher expressed his dissatisfaction with some students who were chatting while their colleague was talking.

\section{Extract 4.11}

1 S8: Active listening show patient we care...

S13: meet you at the field at 8

S14: See you there

T: You should listen to your colleague talking... Show some respect...

Ok...How would you feel when someone talks while you talk ... It is not nice... Say sorry to your colleague...

S13: We sorry

S14: Sorry S8

$\mathrm{T}$ : Continue $\mathrm{S} 8$

(CO7, M26).

S13 and S14 were talking about going to play soccer while another student was explaining the importance of active listening to patients. The teacher immediately interfered and showed that this is not acceptable (line 4). The teacher used imperative (lines $4 \& 6$ ) to express his dissatisfaction. Also, the teacher asked the students to put themselves in the speaker's shoes (line 5) and see how disrespectful such behavior might be to them. Moreover, the teacher asked the students to apologize to their colleagues in the form of an imperative (line 6). The students then apologized to their colleagues (lines $7 \& 8$ ). The teacher then asked the student to continue what he was talking about (line 9) which reflects his power in controlling the proceedings within the lesson.

Extract 4.11 below further illustrates how the teacher expressed his dissatisfaction with the scheduling of the English class to late afternoon. The teacher challenged the head of 
the department's decision in scheduling the English class in the late afternoon, without giving the students enough break time to rest and eat.

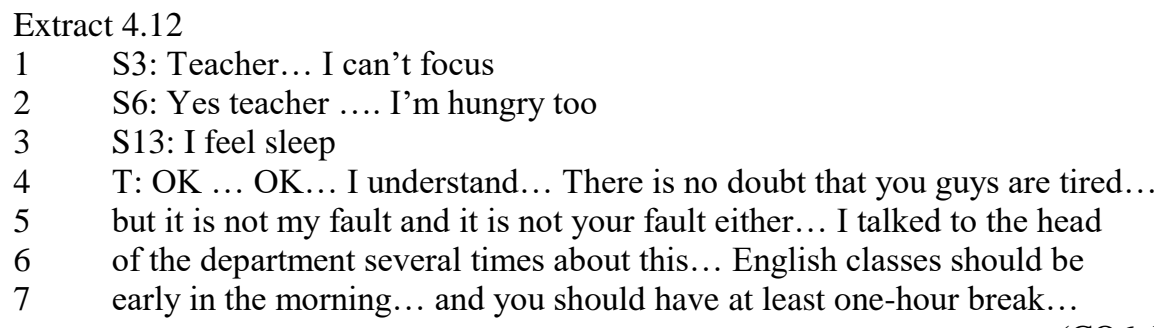

(CO6, M45).

The teacher in the previous extract responded to the student complaint (lines 1, 2, 3). The teacher expressed declaratively his sympathy to the students (line 4) by saying I understand. Questioning the Head of the Department's decision (lines $5 \&$ \&) is a technique used by the teacher to deconstruct the decision and point out the weaknesses of the decision. The teacher made his stance clear regarding this issue (lines $6 \& 7$ ) by stating that the students should have enough break time and English classes should be in the morning. The teacher also expressed his rejection of this decision by saying I talked to the head of the department several times (lines $5 \& 6$ ). The extract above illustrates that he does not only attempt to control how the students should behave in the class but also shows concern about their welfare. We do not know whether it is true that he has talked to the school management, but this episode of talk suggests that he attempts to let the students know that he is determined to get the school management to listen to him, thus emphasizing the identity of a controller.

The teacher constructs the identity of the controller mainly through getting people around him to do what he feels needs to be done. The teacher employed discursive psychology strategies, such as offering justification for his views and attributing particular identities to other people during the construction of his own identity as a controller.

\section{DISCUSSION}

The construction of salient identities can be seen as the teacher attempts to fit into the classroom community (Goffman, 1959; Rashid et al., 2016b). The five salient identities constructed in the classroom are the expert, the counsellor, the student, the storyteller, and the controller. The teacher constructs these desirable identities in the classroom to project the image which enables him to gain acceptance and approval, thus creating a supportive environment. This is in line with the discourse community perspective, members adapt their identities to fit into the community (Goffman, 1959; Zulkffli \& Rashid, 2016.). The teacher in this study draws on certain communicative resources such as narratives and small stories to engage with the students. Also, the teacher positioned himself differently in the classroom and employed non-verbal cues to reflect on his identity and position in the classroom. This is in line with Azizan et al. (2020) and Wortham's (2001) model which explains how different language genres and 
symbolic cues are being used in communications to project identity, voice and positioning.

This study supports the argument that identity is not perpetual; identity is constantly negotiated and re-negotiated (Edwards, 1992; Gee, 2000; Benwell \& Stokoe, 2006; Rashid et al., 2016a) as the findings show that teachers construct multiple identities at different times. For example, a teacher who constructs the identity of a counsellor in an episode of talk may construct the identity of the controller in another episode of talk. It makes sense to propose that the teacher constructs different identities at different times depending on the type of image needed, which demonstrates that the teacher can cope with different voices in the classroom. For example, the teacher fluidly switched his voice from the teacher's voice to the student's voice. This change was evident in the teacher's voice when he switched from the personal pronoun 'I' to 'we' for example. In fact, the teacher echoed several voices in his talk such as the storyteller, the expert, and the counsellor. The fact that the teacher switched seamlessly among multiple identities align with Richards' (2006) and Rashid et al.'s (2016a; 2016b) findings. Teachers use language purposefully to assume a position and therefore align with class members. Although the teacher's voice was more powerful, there were moments where the teacher delegated this role to students and gave the students chances to be in his place and practice his role; for example, during peer feedback and presentation. The teacher moved from being a teacher to be a counsellor and from a teacher to a fellow student.

\section{CONCLUSION}

The teacher's identity in this study is found to be flexible, transformed, and it is subject to challenge through interactions in the classroom. The results show that the teacher fluidly shifted among several identities such as from an expert to a counsellor. The teacher constructs desirable identities in the classroom to project the image which enables him to gain acceptance and approval, thus creating a supportive learning environment. The discursive shift of identity was proven through the use of different linguistic resources such as shifts in pronouns to indicate the shift in positioning.

This study discussed the salient identities displayed by the teacher on classroom interaction from the lens of discursive psychology and discourse analysis. Five constructed identities were discussed. The first identity is the expert. The teacher constructed this identity to enhance the students' experience of learning and to offer guidance and help students to achieve lesson goals. The second constructed identity is counsellor. The teacher constructed this identity to show care to students and how their success is important to him. Therefore, students were encouraged and motivated to keep up their good work. The third identity is the student, mainly constructed by decreasing the power of the teacher and allowing the students to practice the teacher's role. The fourth identity is the storyteller, where the teachers' narratives fit the storytelling genre. The focus of the stories is to introduce the topic, get students' attention and create a friendly atmosphere in the classroom. The fifth identity constructed is the controller, where the teacher challenges and questions the behavior of the people around him to show dissatisfaction with those behaviors or actions. 
The findings from this study have several implications for policy makers and teachers. Firstly, it may be useful for teacher-training programmes to raise awareness of teachers' discursive identities in classrooms so that teachers will be more aware of how their identity may influence their teaching as current teacher-training programmes mainly focus on content knowledge and little attention is given to raise awareness that teachers' identity is an important aspect of classroom teaching and learning. Secondly, the interpretation of the fleeting shift among several identities in the classroom brought to the teacher awareness an image of how identities are constructed and presented and most importantly how useful they can be for classroom management and setting.

\section{REFERENCES}

Abugohar, M. A., Yunus, K., \& Rashid, R. A. (2019). Smartphone applications as a teaching technique for enhancing tertiary learners' speaking skills: Perceptions and practices. International Journal of Emerging Technologies in Learning, 14(9).

Al-Smadi, O. A., Rashid, R.A., \& Altamimi, D.H. (2020). A linguistic ethnography of teacher talk in an English for Medical Purposes Classroom. International Journal of Arabic-English Studies, 20(1), 51-66. DOI: 10.6007/ijarped/v6-i3/3169

Al-Smadi, O.A. \& Rashid, R.A. (2019). Teacher talk in an English for medical purposes classroom. Trends in Social Sciences, 1(1), 57-63.

Aziz, A. H. A. A., Rashid, R.A, \& Zainudin, W. Z. W. (2018). The enactment of the Malaysian common European framework of reference (CEFR): National master trainer's reflection. Indonesian Journal of Applied Linguistics, 8(2), 409-417.

Azizan, M., Ismail, H. H., \& Qaiwer, S. N. (2020). Power and solidarity in positive feedback posting amidst Covid-19 in Malaysia. Journal of Nusantara Studies, 5(2), 329364. https://doi.org/10.24200/jonus.vol5iss2pp329-364

Benwell, B. and Stokoe, E. (2006) Discourse and identity. Edinburgh, UK: Edinburgh University Press.

Bloomfield, D. (2010). Emotions and 'getting by': A pre-service teacher navigating professional experience. Asia-Pacific Journal of Teacher Education, 38(3), 221234.DOI: 10.1080/1359866x.2010.494005.

Davies, B. (1989). The discursive production of the male/female dualism in school settings. Oxford Review of Education, 15(3), 229-241.

Edwards, D. Potter (1992). Discursive psychology. London: Sage.

Edwards, D. Potter (2005) Discursive psychology, mental states and descriptions. In: Te Molder, H. and Potter, J. (Eds.) Conversation and cognition, pp.241-259. Cambridge: Cambridge University Press.

Gee, J. P. (2000). Identity as an analytic lens for research in education. Review of Research in Education, 25(1), 99-125. DOI: 10.2307/1167322. 
Gee, J. P. (2014). An introduction to discourse analysis: Theory and method (4th ed.). London: Routledge.

Goffman, E. (1959). The presentation of self in everyday life. New York: Doubleday.

Haniford, L. C. (2010). Tracing one teacher candidate's discursive identity work. Teaching and Teacher Education, 26(4), 987-996. DOI: 10.1016/j.tate.2009.10.041.

Koca, F. (2017). An investigation of the association between teacher-student relations and school adjustment competencies in Turkey. European Journal of Education Studies, 3(6), 215-225. DOI: 10.5281/zenodo.580129

Lamote, C., \& Engels, N. (2010). The development of student teachers' professional identity. European Journal of Teacher Education, 33(1), 3-18. DOI: 10.1080/02619760903457735.

Lawler, S. (2014). Identity - sociological perspectives ( $2^{\text {nd }}$ ed.). Cambridge: Polity Press.

Mohammadi, H., \& Izadpanah, S. (2019). A study of the relationship between Iranian learners' sociocultural identity and English as a Foreign Language (EFL) learning proficiency. International Journal of Instruction, 12(1), 53-68. https://doi.org/10.29333/iji.2019.1214a

Nor, N. M., \& Ab Rashid, R. (2018). A review of theoretical perspectives on language learning and acquisition. Kasetsart Journal of Social Sciences, 39(1), 161-16.

Othman, J., Mohd Saat, R., Hasan Adli, D. S., \& Senom, F. (2020). Dual language programme: Teachers' beliefs and practices in teaching science through $\begin{array}{lll}\text { English. Journal of Nusantara 255-269. } & \text { Studies, 5(1), }\end{array}$ https://doi.org/10.24200/jonus.vol5iss1pp255-269

Rashid, R. A., Mohamed, S. B., Rahman, M. F. A., \& Shamsuddin, S. N. W. (2017). Developing speaking skills using virtual speaking buddy. International Journal of Emerging Technologies in Learning, 12(05), 195-201.

Rashid, R.A., Wahab, Z., Yunus, K., Ismail, N.S., Yusof, N., Omar, S.S., \& Azmi, M. (2016a). English language teachers as a dissenter on a social networking site. International Journal of Applied Linguistics and English Literature, 5, 72-78. DOI: 10.7575/aiac.ijalel.v.5n.4p.72

Rashid, R.A, Yunus, K., Azmi, N. J., Rahman, S. B. A., \& Yusoff, S. Z. (2016b). The discursive construction of teachers' desirable identity on a social networking site. International Journal of Applied Linguistics and English Literature, 5(5), 139-144.

Richards, K. (2006). 'Being the teacher': Identity and classroom conversation. Applied Linguistics, 27(1), 51-77. DOI:10.1093/applin/ami041.

Riyanto, \& Aryulina, D. (2020). Implementing immediate feedback with unlimited plus bonus points to increase college student learning motivation and achievement. 
International Journal of Instruction, $13(3), \quad 387-400$. https://doi.org/10.29333/iji.2020.13327a

Salinas, D., \& Ayala, M. (2018). EFL student-teachers' identity construction: A case study in Chile. HOW Journal, 25(1), 33-49. https://doi.org/10.19183/how.25.1.380

Thornbury, S. \& Slade, D. (2006) Conversation: From description to pedagogy. Cambridge: Cambridge University Press.

Tnay, J. K. S., Adruce, S. A. Z., Lau, E., Ting, H., Ting, C. Y., \& Sandhu, M. K. (2020). Teacher's engagement in the social and emotional guidance of elementary school students. International Journal of Instruction, 13(3), 827-844. https://doi.org/10.29333/iji.2020.13355a

Trent, J. (2013). From learner to teacher: Practice, language, and identity in a teaching practicum. Asia-Pacific Journal of Teacher Education, 41(4), 426-440. DOI:10.1080/1359866x.2013.838621.

Wortham, S. E. F. (2001). Narratives in action: A strategy for research and analysis. New York: Teachers College Press.

Zare-ee, A., \& Ghasedi, F. (2014). Professional identity construction issues in becoming an English teacher. Procedia-Social and Behavioral Sciences, 98, 1991-1995. DOI: 10.1016/j.sbspro.2014.03.633.

Zulkffli, M. A., \& Ab Rashid, R. (2016). A discursive psychological analysis of Islamic sermons on homosexuality. International Journal of Applied Linguistics and English Literature, 5(6), 190-198. 